\title{
Views of Trainee Science Teachers in Kuwait Regarding the NoS Dimensions and Their Conception of Creativity in Science Education
}

\author{
Ahmad Shallal Alshammari ${ }^{1}$, Hamed Jassim Alsahou ${ }^{2}$, Joza M Alshemmari ${ }^{1}$ \\ ${ }^{1}$ Associate Professor at The Department of Curriculum and instruction, College of Basic Education, The Public \\ Authority for Applied Education and Training, Kuwait \\ ${ }^{2}$ Associate Professor at The Department of Special Education, College of Basic Education, The Public Authority for \\ Applied Education and Training, Kuwait
}

Correspondence: Hamed Alsahou, College of Basic Education, The Public Authority for Applied Education and Training, Kuwait. E-mail: Dr.alsahou@hotmail.com, hj.alsahow@paaet.edu.kw

Received: Oct. 8, $2020 \quad$ Accepted: Nov. 4, $2020 \quad$ Online Published: Nov. 5, 2020

doi:10.11114/jets.v8i12.5073 URL: https://doi.org/10.11114/jets.v8i12.5073

\begin{abstract}
Science educators are often advised to pay attention to trainee teachers' views on issues related to education, particularly the nature of science (NoS). Views on the NoS can be translated into pedagogical practices and then transferred to students; therefore, teachers should hold informed views about the NoS. This study sought to explore the views of trainee science teachers in Kuwait about the NoS and its aspects or dimensions. It also aimed to identify the possible connections among the NoS dimensions and teachers' views on creativity in science. This multi-method study involved 152 trainee science teachers. The research instruments consisted of a questionnaire about teachers' views of the nature of science (VNoS), a questionnaire about teachers' views of creativity in science education, and semi-structured interviews. The findings revealed that trainee science teachers hold naïve and sometimes perplexing views of the NoS dimensions, and they are more likely to follow a traditional positivist worldview when they discuss the nature of scientific knowledge. Also, the findings revealed trainee teachers' views of creativity in science education as well as significant correlations among six NoS dimensions and creativity. Detailed findings are discussed to draw conclusions and address possible suggestions for science educators and for the community of science education research.
\end{abstract}

Keywords: Nature of science, Scientific Creativity, Trainee Teachers, Teachers' views, Kuwait

\section{Introduction}

\subsection{Creativity in Science Education}

Creative education is increasingly attracting educators due to its impact on preparing a generation able to deal with future changes. Education is no longer dependent on preparing cadres for the labor market, but rather to prepare cadres capable of creating new job markets. Therefore, educators are interested in developing students' creative skills and providing them with opportunities that help them develop imaginative thinking and problem-solving skills in various school subjects. There is also a clear interest in developing scientific creativity by incorporating creative skills into the subject of school science. A growing body of recent literature has advocated the idea of fostering students' creativity in science education, to increase students' productivity and innovation within the scientific domain (Akcanca \& Cerrah Ozsevgec, 2018).

Ripple (1999) defined, creative education as a mixture of capabilities, skills, perspectives, stimulation, and other factors. In the field of creative education, educational researchers often study three main areas: teaching for creativity, teaching creatively, and creative learning. 


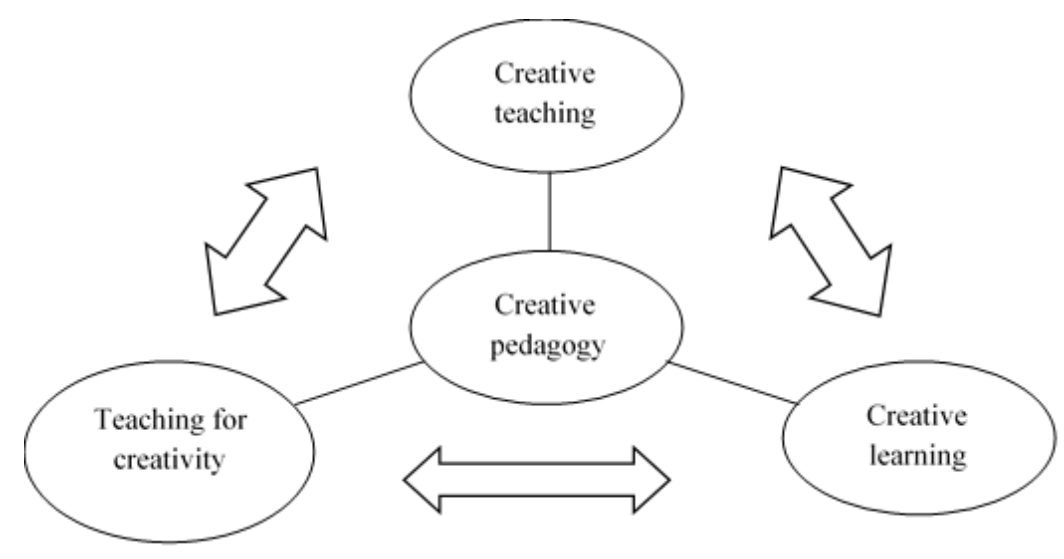

Figure 1. Three elements of creative pedagogy (Lin, 2011)

These three concepts are intertwined with one another and are the main elements of creative education. The concept of teaching for creativity is based on pedagogical practices and educational implications that aim to strengthen students' creative endeavors; meanwhile the concept of teaching creatively is more likely to be represented by effective teaching approaches (Jeffrey \& Craft, 2004). Meanwhile, the concept of creative learning focuses on students' interactions with classroom activities based on teaching for creativity and creative teaching (Jeffrey, 2006). When looking carefully at the three concepts, the role of the teacher in applying these concepts and contributing to achieving the goals of creative education can be observed. Teachers are required to apply pedagogical approaches that manifest students' creative thinking; to do so, they need to adopt more creative and effective teaching practices. A NACCCE (1999) report stated that "teaching for creativity involves teaching creatively" (p. 90) and concluded that, whenever the teacher is creative and applies effective and original strategies, the interaction of students is authentic and creative, and vice versa. Therefore, it is important for the teacher to have positive and advanced views on the concept of creative education in various school subjects and know how to achieve them on the ground. In particular, science teachers, who prepare future scientists, are distinguished by their ability to discover and create scientific solutions to future challenges.

Accordingly, empirical works have focused on science teachers' understanding of scientific creativity and the implications for increasing students' innovative thinking in the classroom. However, most of these empirical investigations have concluded that science teachers hold a naïve and simple understanding of scientific creativity (Hong \& Kang, 2010; Liu \& Lin, 2014; Newton \& Newton, 2010) and poor classroom implications to support creative thinking (Alsahou, 2015). Other studies have concluded that teachers connect creativity with art and music education (Aljughaiman \& Mowrer-Reynolds, 2005; Diakidoy \& Kanari, 1999; Fryer, 1996; Kampylis, 2010; Mohammed, 2006); meanwhile they view science education as less creative and more static as a set of unchanging facts and universal laws (Johnston, 2009; Osborne \& Dillon, 2008). Such misunderstanding could raise questions regarding how science teachers view the nature of science (NoS): Do teachers' views of scientific creativity connect with their views of NoS (Alsahou \& Alsammari, 2019)?

Research studies have demonstrated the positive effects of integrating the NoS into science education to improve students' understanding of science content (McComas, Clough, \& Almazroa, 1998) and students' scientific literacy (Hodson, 2009). Thus, a number of science education scholars argue for the essence of teachers' understanding of the NoS because their NoS views would affect their pedagogical practices, scientific conceptions, and the NoS content.

There are several benefits when science teachers hold informed views about the NoS. As shown in previous literature, the importance of the NoS lies in numerous points, from which we can mention the following: knowledge of the NoS as a fundamental component of science literacy that should be taught in science class (Hodson, 2009); people's scientific knowledge (Park, Nielsen, \& Woodruff, 2013); offering better understanding of scientific content (McComas et al., 1998); increasing students' curiosity for learning science (Sjøberg, 2010, cited in Leden \& Hansson, 2017); and developing teachers' understanding, which in turn develops their pedagogical approaches and enhances the quality of teaching science (Hanuscin, Lee, \& Akerson, 2010).

Despite the acknowledgment of the crucial role of the NoS in science education and teachers' NoS views, there is still a lack of research on teachers' views of the NoS (Leden \& Hansson, 2017). Thus, the current study aims to explore the trainee science teachers' views of both the NoS and creativity in science education. 


\subsection{Dimensions of the NoS}

A specific definition of the NoS is hard to determine as it is a cause of disagreement among philosophers, historians, sociologists, and science educators (Abd-El-Khalick, 2001). However, Clough and Olson (2007, p. 143) have come up with the following definition:

$[\mathrm{NoS}]$ is often used by science educators to refer to issues such as what science is, how it works, the epistemological and ontological foundations of science, how scientists' function as a social group and how society influences and reacts to scientific endeavors.

For decades, scientists have been trying to define the concept of the NoS based on the qualities of scientific knowledge. These attempts resulted in a set of features or dimensions that describe the NoS. For example, Showalter (1974) saw the NoS as being tentative, communal, replicable, probabilistic, humanistic, momentous, universal, exceptional, and experimental. Rubba and Anderson (1978) identified six features to describe scientific knowledge, describing the NoS as ethical, creative, evolutionary, measurable, standardized, and simplified. Kimball (1967) named several aspects of the NoS, such as curiosity, comprehensiveness, simplicity, multi-method, inter-subjective, and tentativeness.

The current study adopted one of the most famous recent sets of dimensions recognized by Abd-El-Khalick, Bell, and Lederman (1998) to define the nature of scientific knowledge. This set of dimensions is usually used in contemporary studies because it covers almost all the constituent elements mentioned by philosophers over the last five decades. Hence, it is important here to mention the adopted dimensions as follows:

- Tentative

- Empirically based

- Theory-laden (subjective)

- Composed of multiple methods

- Socioculturally influenced

- Produced by human inference and imagination

- Differentiation between observation and inference

- Functions and relationships between scientific laws and theories

\subsection{Teachers' Views of NoS}

Teaching science in the classroom by connecting it to the NoS depends completely on the teachers and how they view the NoS. Teachers' understanding of the NoS leads them to provide more advanced scientific teaching for their students. However, studies have determined that teachers have difficulties using the NoS in science classrooms and their views about the NoS are simple and inadequate. For example, Mihladiz and Doğan (2014) investigated science teachers' views of the NoS and their knowledge about the place of the NoS in science teaching. Mihladiz and Doğan (2014) found that science teachers' views on the NoS were naïve and lacking and that they generally had outdated views on science and its aspects. When they were questioned about their opinion on the place of the NoS in teaching science, their explanations were superficial. Furthermore, although teachers knew of the importance of the NoS, it was rarely mentioned in science teaching programs (Mihladiz \& Doğan, 2014). Another study conducted by Aslan and Taşar (2013) reached similar conclusions after examining the views of 75 science teachers about the NoS.

The views of trainee teachers are not very different from those of in-service teachers regarding the conceptions of the NoS. For instance, a recent study conducted by Sairattanain (2018) found that only $12.4 \%$ of the research sample held informed views about the NoS; meanwhile, the majority of participants held either intermediate or naïve views. Also, Aydemir, Ugras, Cambay, and Kilic (2017) assessed trainee science teachers' views on the NoS and scientific inquiry. They found that trainee teachers had inadequate views about the NoS and scientific inquiry. They attributed this to teachers' insufficient learning about the NoS and scientific inquiry at the university level. Undergraduate students need to be well educated to know the main elements of NoS and scientific inquiry that will help them in their careers to teach the NoS.

Karişan and Cebesoy (2018) also explored trainee science teachers' views about the NoS; a qualitative research methodology was used to collect the data. This study showed that trainee science teachers are more informed about the NoS and its aspects (Karişan \& Cebesoy, 2018). These teachers gave high importance to the NoS and developing students' understanding of it as an important part of science. However, when the teachers were questioned about specific aspects of the NoS, it was observed that more than half were informed about inferential NoS, whereas almost half of them lacked insight on subjective NoS (Karişan \& Cebesoy, 2018). 


\subsection{Research Questions}

From the preceding review, it can be concluded that, despite the literature acknowledging the importance of understanding the NoS and integrating it into science classroom activities, teachers are more likely to have insufficient understandings of it. In addition, limited studies have examined teachers' views regarding the NoS (Turgut, Es, Altan, \& Ozturk, 2016). Therefore, more studies should be conducted in different cultures to have a clear picture of teachers' views about the NoS. The aim of the current study is to explore trainee science teachers' views about the NoS in Kuwait. The study seeks to answer the following questions:

1- How do trainee teachers perceive the dimensions of the NoS?

2- What are the significant differences in the dimensions of NoS, based on some demographic variables?

3- How do trainee teachers perceive creativity in science education?

4- To what extent do the dimensions of NoS correlate with conceptions of scientific creativity?

\section{Methodology}

The philosophical assumptions behind the current study are derived from the interpretive paradigm. The research design is based on a mixed-methods strategy, where quantitative and qualitative approaches are applied. The methods used are questionnaires and semi-structured interviews, aiming to collect descriptive, exploratory, and narrative data.

\subsection{Participants}

the College of Basic Education offers science education program for prospective teachers, who will teach general science education for elementary and intermidate schools. The program offers courses from different scientific domains such as biology, chemistry, physicis, geology and so on.

The questionnaire was distributed by hand to 185 Kuwaiti trainee science teachers at the College of Basic Education in Kuwait. The return rate was almost 82\%: 152 individuals responded to the questionnaire. This sample comprised 92 female $(60.5 \%)$ and 60 males (39.5\%) science teachers. The student teachers ranged from under 18 years old to over 30 years old. The questionnaire sample included all the students enrolled in the bachelor's degree in science education, comprising first year (12.5\%), second year (28.9\%), third year (32.9\%), and fourth year (25.7\%).

Moreover, the researcher conducted follow-up interviews with interviewees in order to explore more complicated views regarding the dimensions of the NoS as well as creativity in science. Interviewees were selected from the fourth-year students based on three criteria. First, they passed the relevant courses, such as the methods of teaching science and the methods of general teaching courses. Second, they had passed most of the compulsory and elective courses of the department of science. Finally, the quantitative results showed statistical differences between the fourth-year students and the students of other years, with the former having higher means than the latter. Thus, all fourth-year students who completed the questionnaire were asked to participate in an interview; 18 students agreed to be interviewed ( 5 males and 13 females).

\subsection{Data Collection}

The study first applied the Views on Science and Education Questionnaire (VOSE) developed by Chen (2006b), after reducing it. The VOSE measures two areas of focus: views on the NoS and attitude toward teaching science. However, the current study focused only on views of the NoS. Thus, the attitude toward teaching science was excluded in the current study.

The VOSE emphasizes seven aspects of the NoS that previous studies have examined (e.g., Good et al., 2000; Kourany, 1998; Schwartz \& Lederman, 2002). The seven aspects are attentiveness to scientific knowledge; nature of observation; scientific methods; hypotheses, laws, and theories; imagination; validation of scientific knowledge; and objectivity and subjectivity in science.

The modified and reduced VOSE consisted of 42 items headed by nine questions or statements. Each item was ranked based on a 5-point response scale ranging from "strongly agree" to "strongly disagree." Many of the items start with yes or no, followed by justifications that reflect the participant's point of view. Chen (2006a) adopted a specific scoring scheme for producing inferential data, which the current study also used. 
Table 1. NoS Dimensions, Philosophical Positions, and Items Tested by VOSE

\begin{tabular}{|c|c|c|}
\hline Dimension & Position & Items \\
\hline \multirow[t]{3}{*}{ Tentativeness } & Revolutionary & $4 \mathrm{~A}$ \\
\hline & Cumulative & $4 \mathrm{~B}$ \\
\hline & Evolutionary & $4 \mathrm{C}$ \\
\hline \multirow[t]{2}{*}{ Nature of observation } & Theory-laden & $8 \mathrm{~A}, 8 \mathrm{~B}, 8 \mathrm{E}$ \\
\hline & Theory-independent & $8 \mathrm{C}, 8 \mathrm{D}$ \\
\hline \multirow[t]{2}{*}{ Scientific methods } & Universal scientific method & 9A, 9B, 9F \\
\hline & Diverse methods & $9 \mathrm{C}, 9 \mathrm{D}, 9 \mathrm{E}$ \\
\hline \multirow{3}{*}{$\begin{array}{l}\text { Theories and laws } \\
\text { "Epistemology" }\end{array}$} & Discovered & 5A, 5B (Theory) \\
\hline & & $6 \mathrm{~A}, 6 \mathrm{~B}(\mathrm{Law})$ \\
\hline & Invented & $\begin{array}{l}5 \mathrm{D}, 5 \mathrm{E}, 5 \mathrm{~F} \text { (Theory) 6D, } \\
6 \mathrm{E} \text { (Law) }\end{array}$ \\
\hline \multirow{2}{*}{$\begin{array}{l}\text { Theories and laws } \\
\text { "Comparison" }\end{array}$} & Laws being more certain & 7A, 7B \\
\hline & Different types of ideas & 7C, 7D \\
\hline \multirow[t]{2}{*}{ Use of imagination } & Yes & $3 \mathrm{~A}, 3 \mathrm{~B}$ \\
\hline & No & $3 \mathrm{C}, 3 \mathrm{D}, 3 \mathrm{E}$ \\
\hline \multirow{5}{*}{$\begin{array}{l}\text { Validation of scientific } \\
\text { knowledge }\end{array}$} & Empirical evidence & $1 \mathrm{~A}, 1 \mathrm{H}$ \\
\hline & Paradigm & $1 \mathrm{C}, 1 \mathrm{~F}$ \\
\hline & Parsimony & 1D \\
\hline & Authority & $1 \mathrm{E}$ \\
\hline & Intuition & $1 \mathrm{G}$ \\
\hline \multirow{7}{*}{ Total subjectivity } & Parsimony & $1 \mathrm{D}$ \\
\hline & Authority & $1 \mathrm{E}$ \\
\hline & Paradigm & $1 \mathrm{C}, 1 \mathrm{~F}, 8 \mathrm{~A}, 8 \mathrm{~B}$ \\
\hline & Personal factors & $1 \mathrm{G}, 8 \mathrm{~A}$ \\
\hline & Sociocultural factors & $2 \mathrm{~A}, 2 \mathrm{~B}$ \\
\hline & Use of imagination & $3 \mathrm{~A}, 3 \mathrm{~B}$ \\
\hline & Subjective methodology & 9D \\
\hline \multirow{5}{*}{ Total objectivity } & Use no imagination & $3 \mathrm{C}, 3 \mathrm{E}$ \\
\hline & No influence of socio-culture & $2 \mathrm{C}, 2 \mathrm{D}$ \\
\hline & Based on experimental facts & $5 \mathrm{~B}, 6 \mathrm{~B}, 8 \mathrm{D}$ \\
\hline & No influence of personal beliefs & $8 \mathrm{C}$ \\
\hline & Objective methodology & $8 \mathrm{E}, 9 \mathrm{~A}, 9 \mathrm{~B}$ \\
\hline
\end{tabular}

Note: Table adapted from Chen (2006b)

For illustration, the following statement is about the comparison between scientific laws and theories (statement 7):

In comparison to law, theories have less evidence to support them.

A. Yes, theories are not as definite as laws.

B. Yes, if a theory stands up to many tests it will eventually become a law; therefore, a law has more supporting evidence.

C. Not quite. Some theories have more supporting evidence than some laws.

D. No, theories and laws are different types of ideas. They cannot be compared.

The second instrument aimed to explore teachers' concept of creativity in science education; a questionnaire was used in order to collect data. The questionnaire, entitled "Teachers' views about creativity in science," was developed by Alsahou \& Alsammari (2019). It comprises, sequentially, five demographic questions, nine closed-ended questions about creativity in science education, and eight open-ended questions about creativity specifically in science education. The participants were asked to respond to the statements using a 5-point Likert scale ranging from "strongly agree" to "strongly disagree." Some examples of close-ended statements from this questionnaire include the following: "creativity and imagination are essential elements in the formation of scientific knowledge"; "creativity occurs only in the fields of visual arts, music, drama, and artistic performance"; and "fostering creativity is essential for improving the educational performance of students in science."

The third instrument was a semi-structured interview, which was chosen to enable the collection of data from trainee science teachers' perspectives because a one-to-one conversation is an efficient approach for exploring the interviewees' 
feelings, attitudes, and opinions (Wellington, 2000). Consequently, the conversation will not only lead to gathering the participants' ideas, but also evaluating, clarifying, and investigating their responses, as Burns (1997) suggested. The interview schedule consisted of three sections: ice-breaking questions focused on interviewee's personal and academic information; questions focused on interviewees' concept of creativity in science education; and questions focused on interviewees' views of the NoS dimensions. All the interviews were conducted in the researcher's office and lasted from 15 to 23 minutes.

\subsection{Piloting the Research Instruments}

The modified version of the VOSE was translated from English into Arabic and then back into English to achieve the required quality in translation as this method is one of the most common quality assessment methods in social research across different languages and cultures (Tyupa, 2011). The two copies were then presented to two translators to examine the initial version in preparation for formulating the revised final version. The translated version of the questionnaire was presented to three professors in the field of science education to express their opinion on the clarity of the phrases and the accuracy of the language.

With regard to the second instrument, the researchers took steps to ensure the quality of the scale. They compared the inventory items with different research tools from similar studies (i.e., Alsahou, 2015; Hong \& Kang, 2009; Lee \& Kim, 2005; Liu \& Lin, 2014; Newton \& Newton, 2009, 2011; Park, Lee, Oliver, \& Crammond, 2006) and then presented the results to three professors in the field of gifted and creative education to check the appropriateness and clarity of the inventory. The Cronbach's alpha of the questionnaire was at a satisfactory level $(\alpha=0.822)$. "The sub-scale of views on creative education reaches acceptable reliability, $\alpha=0.722$; meanwhile, the sub-scale of creativity in science subject also reaches acceptable reliability, $\alpha=0.706$ " (Alsahou \& Alsammari, 2019, p. 39).

The interview schedule was also reviewed by three professors in the field of science curriculum and pedagogies. In addition, five students enrolled in a science education course were asked to check the clarity of the questions. These procedures led to modifications before collecting the data.

\subsection{Data Analysis}

Quantitative data were fed into the Statistical Package for Social Sciences (SPSS, ver. 23.0) software program. Using SPSS, two kinds of statistical analyses were performed: descriptive and inferential. The descriptive analysis is represented by percentage, standard deviations, means, and frequencies. Meanwhile, the inferential analysis is represented by a correlation analysis that facilitates the identification of possible statistical comparisons and relationships among the overall responses.

With regard to the qualitative data, the raw data were fed into the Max Qualitative Data Analysis (MAXQDA, ver. 11.0) software program. Transcripts of the semi-structured interviews and open-ended questions were analyzed using a coding frame strategy. The coding frame approach enabled the researchers to narrow the various responses to a few main categories or themes. Creswell's (2002) code reduction model was adopted to analyze the qualitative data using key concept matrices. This analysis strategy is a practical method for reducing the broad responses to specific themes and categories. Creswell's coding model has five practical levels: reading the text data, dividing the texts into segments of information, coding the segments, narrowing and reducing the codes, and collapsing the codes into themes and categories. During this process, the researchers kept recording thoughts in the form of memos.

\section{Results}

The findings are summarized within three sections in which quantitative and qualitative results are presented together. The first section presents trainee teachers' views of the NoS dimensions, followed by a presentation of trainee teachers' views of creativity in science education in the second section. The correlation between the NoS dimensions and creativity in science education is presented in the last section. All trainee teachers' names used are pseudonyms to anonymize their real names. 


\subsection{Trainee Teachers' Views of NoS Dimensions}

The statistical results of trainee teachers' views of the NoS dimensions are presented in this section.

Table 2. Trainee Teachers' Views of NoS Dimensions

\begin{tabular}{|c|c|c|c|c|}
\hline Dimension of NoS & Position & $N$ & $M$ & $S D$ \\
\hline \multirow[t]{2}{*}{ Nature of observation } & Theory-laden & 152 & 3.54 & .63 \\
\hline & Theory-independent & & 3.38 & .92 \\
\hline \multirow[t]{2}{*}{ Scientific methods } & Universal methods & 152 & 3.99 & .62 \\
\hline & Diverse methods & & 3.14 & .75 \\
\hline \multirow[t]{3}{*}{ Sociocultural and empirical factors } & Personal factors & 152 & 3.16 & .69 \\
\hline & Cultural factors & & 3.38 & .89 \\
\hline & Based on experimental facts & & 3.78 & .54 \\
\hline \multirow[t]{2}{*}{ Use of imagination } & Yes & 152 & 3.45 & 1.26 \\
\hline & No & & 3.26 & 1.10 \\
\hline \multirow[t]{3}{*}{ Tentativeness } & Revolutionary & 152 & 3.87 & .98 \\
\hline & Cumulative & & 3.99 & .80 \\
\hline & Evolutionary & & 3.84 & 1.01 \\
\hline \multirow[t]{5}{*}{ Validation of scientific knowledge } & Empirical evidence & 152 & 3.46 & .70 \\
\hline & Paradigm & & 3.09 & .88 \\
\hline & Parsimony & & 2.44 & 1.02 \\
\hline & Authority & & 2.61 & 1.09 \\
\hline & Intuition & & 2.93 & 1.2 \\
\hline Scientific theories (epistemology*) & Invented or discovered & 152 & 2.09 & .66 \\
\hline \multicolumn{5}{|l|}{ (epistemology $*)$} \\
\hline \multirow{2}{*}{$\begin{array}{l}\text { Scientific theories and laws } \\
\text { (comparison } * *)\end{array}$} & Laws being more certain & 152 & 3.74 & .87 \\
\hline & Different types of ideas & & 3.47 & .79 \\
\hline
\end{tabular}

Note: *High mean scores indicate science is invented; low mean scores indicate science is discovered. **High mean scores indicate a position more in agreement with $\operatorname{NoS}$ dimensions (lowest $M=1$, highest $M=5$ ).

As demonstrated in Table 2, the nature of observation is seen as being more theory-laden than theory-independent, although the difference between the two positions is not high in terms of means $(M=3.54, S D=.63$ and $M=3.38, S D$ $=.92$, respectively). In contrast, there is a clear difference between the means in the dimension of scientific methods. More specifically, science trainee teachers recognize that there are universal methods $(M=3.99, S D=.62)$ of forming knowledge rather than diverse methods $(M=3.14, S D=.75)$. Trainee teachers hold neutral views about the influence of cultural factors $(M=3.38, S D=.89)$ as well as personal factors $(M=3.16, S D=.69)$ of scientists on their scientific work and interpretation. In addition, trainee teachers apparently agreed that the NoS is based on experimental facts $(M=$ $3.78, S D=.54$ ) more than sociocultural factors. Yet the participants had conflicting views on the use of imagination as a dimension of the NoS. When comparing the mean of items that acknowledge the use of imagination to form and produce scientific knowledge $(M=3.45, S D=1.26)$, it is not much different from the mean of items that indicate that the NoS is free from the influence of scientists' and researchers' imaginations $(M=3.26, S D=1.10)$.

The qualitative data analysis revealed that some interviewees connected the existence of different theories about particular phenomena with the cultural and personal impacts of the scientists. As one interviewee explained, "every scientist understands [natural phenomena] based on his own perspective or angle; as a result, there are gaps among scientists" opinions and interpretations" (Nora). Another interviewee claimed that "any scientist or researcher holds principles and values... so his work aligns with these principles" (Fatema). As a result, "researchers' beliefs and principles affect their research findings" (Marrim). Despite these comments, all the interviewees pointed to the importance of the empirical background of natural sciences as they believed that what distinguishes the NoS from the nature of other fields of knowledge is the empirical facts. Some interviewees stated that scientific knowledge is value free and based on universal methods; therefore, scientists should not be affected by sociocultural and personal factors or even their imagination because scientific knowledge stands on empirical evidence. 
Moreover, the findings revealed teachers' views of the tentativeness of NoS, relying on three explanations: revolutionary, cumulative, and evolutionary. As Table 2 indicates, the means of the three positions are very close: $M=$ 3.84 (evolutionary), $M=3.87$ (revolutionary), and $M=3.99$ (cumulative). Thus, trainee teachers agreed with the three positions, indicating inadequate or naïve understanding of the tentativeness of science. The table also illustrates the five positions of how scientific knowledge is validated and accepted by scientists; most positions appear with low means, ranging from $M=2.44$ to $M=3.09$, except empirical evidence $(M=3.46, S D=.7)$. As a result, trainee science teachers view the intuition and authority of scientists - and even the paradigm and simplicity of knowledge - as weak justifications or a poor approach to validating scientific knowledge; meanwhile, empirical evidence is seen as a good approach for validating scientific knowledge.

The interviewees first distinguished between the validity of laws and the validity of theories: most of them viewed scientific laws as absolute truth, which cannot be changed, and "inevitable facts" (Elham). Consequently, scientific laws are not tentative from the perspective of student teachers, who also revealed that such laws are valid knowledge. They believed that the possibility of changing scientific knowledge is limited to scientific theories and hypotheses. Thus, scientific theories are tentative and "subject to change at any time" (Ahmed).

Furthermore, the epistemologies of both theory and law scored very low means ( $M=2.09$, and $M=2.63$, respectively). In other words, participants' epistemological position is close to the notion that science is discovered, not invented. According to trainee teachers' responses, scientists are often limited to discovering science that already exists in nature; such a position limits the role of scientists' imagination, creativity, and invention during the construction of scientific knowledge. Participants compared laws with theories in terms of credibility on the one hand and difference on the other. In the first place, they viewed laws as being more certain than theories $(M=3.74, S D=.87)$; then they viewed theories and laws as different types of ideas $(M=3.47, S D=.79)$.

Qualitative results are consistent with numerical results, where the interviewees indicated that there is a difference between laws and theories in the scientific domain. The interviewees believed that scientific laws are unchangeable facts. Words such as "stable," "fixed," "consistent," and "unchangeable" were commonly coded when the interviewees revealed their views about scientific laws. For example, one female student teacher stated that "scientific law is solid fact... and unchangeable, ... and it cannot be rejected" (Alanoud). Fifteen interviewees agreed with this comment, justifying the inevitability of laws. Meanwhile, theories were seen as changeable and questionable knowledge by all interviewees. For example, a male interviewee said "[theories are] not solid science because they are changeable and can be rejected anytime" (Ahmed). The interviewees stated that the aim of theories includes "providing possible explanations of specific phenomena" (Hanan); however, these explanations "do not stand on enough information and evidence" (Abdoallah).

Finally, positions referring to total subjectivity and total objectivity were computed to calculate the total scores. The results revealed that the total objectivity score $(M=3.90, S D=.83)$ was higher than the total subjectivity score $(M=$ $3.16, S D=.54)$.

Overall, the means of dimensions indicated that participants did not hold informed views of the NoS; rather, they appeared to hold naïve viewpoints about most of the dimensions. The data analysis showed that trainee teachers see scientific knowledge based on universal method and experimental facts and evidence in the first stance, whereas they appeared to hold confused opinions about other dimensions. They distinguished between the nature of scientific laws and the nature of scientific theories, where laws are objective knowledge, unlike theories, which have a subjective nature. Nevertheless, when interviewees were asked about their concepts about science education, they supported an objectivist standpoint. They felt that science is different from other fields. For example, one interviewee compared the scientific domain with other domains:

Science means objective and logical knowledge... and it's based on specific principles, starting from discovering problems, conducting research, building up theories, solving the problem, [to] finally drawing scientific law. However, knowledge of other domains could be right or wrong and depends on various perspectives. (Alanood)

A number of interviewees made similar comparisons between science and other domains to conclude that science is more objective and evidence-based (i.e., Alanood, Nora, Fatema, Reem, and Khaled).

\subsection{The Dimensions of NoS Among Groups}

the findings revealed the significant differences among groups, there are several differences between dimensions of NoS regarding gender and academic year groups. An independent samples t-test was conducted to examine whether there are significant differences in aspects of the NoS between the levels, based on the gender of interviewees. 
Table 3. Significant differences in NoS dimensions based on gender

\begin{tabular}{llllllll}
\hline Position & gender & $\mathrm{N}$ & $M$ & $S D$ & $\mathrm{df}$ & T-test & Sig \\
\hline Subjectivity & Male & 60 & 3.29 & .52 & 150 & 3.07 & .003 \\
& Female & 92 & 3.02 & .52 & & & \\
Parsimony & Male & 60 & 2.73 & 1.13 & 150 & 2.93 & .004 \\
& Female & 92 & 2.25 & .89 & & & \\
Personal affect & Male & 60 & 3.76 & .81 & 150 & 3.61 & .000 \\
& Female & 92 & 3.26 & .84 & & & \\
Empirical & Male & 60 & 3.62 & .63 & 150 & 2.36 & .019 \\
evidence & Female & 92 & 3.35 & .73 & & & \\
Revolutionary & Male & 60 & 4.17 & .80 & 50 & 3.11 & .002 \\
& Female & 92 & 3.67 & 1.03 & & &
\end{tabular}

There were 92 female trainee teachers and 60 male trainee teachers. In table 3, the result of the t-test was not significant in most of the dimensions, apart from five. Significant differences were found in these five dimensions, in which males scored significantly higher means than females. Firstly, the largest gap between males and females equally appeared in the personal beliefs position and the revolutionary position: the difference between the mean of males and the mean of females is equal to 0.5 (personal beliefs $t(150)=3.61, p=.000)$; revolutionary $t(150)=3.11, p=.002$ ). Significant differences are obvious in parsimony, subjectivity, and empirical evidence when means are compared, in which the means of males were $(M=2.73, M=3.29, M=3.62$ respectively) and the means of females were $(M=2.25, M=3.02$, $M=3.35$ respectively).

Table 4. A one-way between-groups analysis of variance and LSD test

\begin{tabular}{|c|c|c|c|c|c|c|}
\hline Position & Group & $M(S D)$ & $\mathrm{F}(3.148)$ & Other groups & $M(S D)$ & Sig \\
\hline \multirow[t]{2}{*}{ Cumulative } & \multirow[t]{2}{*}{ Fourth year } & \multirow[t]{2}{*}{$4.21(.76)$} & \multirow[t]{2}{*}{3.118} & Second year & $3.7(.82)$ & .04 \\
\hline & & & & Third year & $4.04(.81)$ & .004 \\
\hline \multirow{2}{*}{$\begin{array}{l}\text { Theory } \\
\text { invented }\end{array}$} & \multirow[t]{2}{*}{ Fourth year } & \multirow[t]{2}{*}{$2.69(.76)$} & \multirow[t]{2}{*}{2.919} & First year & $2.38(.72)$ & .034 \\
\hline & & & & Second year & $2.59(.66)$ & .007 \\
\hline \multirow[t]{2}{*}{ Paradigm } & \multirow[t]{2}{*}{ Fourth year } & \multirow[t]{2}{*}{$3.53(.61)$} & \multirow[t]{2}{*}{2.935} & Second year & $3.17(.49)$ & .006 \\
\hline & & & & Third year & $3.25(.60)$ & .026 \\
\hline \multirow{2}{*}{$\begin{array}{l}\text { Personal } \\
\text { beliefs }\end{array}$} & \multirow[t]{2}{*}{ Fourth year } & \multirow[t]{2}{*}{$3.68(.74)$} & \multirow[t]{2}{*}{3.042} & First year & $3.11(.83)$ & .016 \\
\hline & & & & Third year & $3.27(.94)$ & .030 \\
\hline \multirow[t]{2}{*}{ Parsimony } & \multirow[t]{2}{*}{ Fourth year } & \multirow[t]{2}{*}{$2.80(1.08)$} & \multirow[t]{2}{*}{3.474} & First year & $2(.58)$ & .005 \\
\hline & & & & Second year & $2.25(1.01)$ & .014 \\
\hline \multirow[t]{2}{*}{ Subjectivity } & \multirow[t]{2}{*}{ Fourth year } & \multirow[t]{2}{*}{$3.33(.54)$} & \multirow[t]{2}{*}{4.675} & First year & $3(.52)$ & .033 \\
\hline & & & & Second year & $2.93(.57)$ & .000 \\
\hline
\end{tabular}

Academic years is another variable that was examined to find out any differences among trainee science teachers; hence, a one-way between-groups analysis was conducted followed by a post-hoc test to highlight the details of significant indicators. According to table 8 , there are significant differences among the groups in six positions. It also reveals that student teachers of year four always score the highest mean when it is compared with groups of other years.

\subsection{Trainee Teachers' Views of Creativity in Science Education}

The second questionnaire focused on participants' views about creativity in science education. As Table 5 demonstrates, the overall mean of trainee teachers' views of creativity in science education is $3.76(S D=.39)$. 
Table 5. Trainee Teachers' Views of Creativity in the Science Education

\begin{tabular}{|c|c|c|c|c|c|c|c|c|}
\hline$N$ & Item & $\begin{array}{l}\text { Strongly } \\
\text { disagree } \\
N(\%)\end{array}$ & $\begin{array}{l}\text { Disagree } \\
N(\%)\end{array}$ & $\begin{array}{l}\text { Neutral } \\
N(\%)\end{array}$ & $\begin{array}{l}\text { Agree } \\
N(\%)\end{array}$ & $\begin{array}{l}\text { Strongly } \\
\text { agree } \\
N(\%)\end{array}$ & $M$ & $S D$ \\
\hline 1 & Creativity in science can be assessed & $\begin{array}{l}1 \\
(.7)\end{array}$ & $\begin{array}{l}9 \\
(5.9)\end{array}$ & $\begin{array}{l}27 \\
(17.8)\end{array}$ & $\begin{array}{l}73 \\
(48)\end{array}$ & $\begin{array}{l}42 \\
(27.6)\end{array}$ & 3.96 & .868 \\
\hline 2 & $\begin{array}{l}\text { Creativity in science can be seen by } \\
\text { everyone }\end{array}$ & $\begin{array}{l}19 \\
(12.5)\end{array}$ & $50(32.9)$ & $\begin{array}{l}47 \\
(30.9)\end{array}$ & $\begin{array}{l}23 \\
(15.1)\end{array}$ & $\begin{array}{l}13 \\
(8.6)\end{array}$ & 2.74 & 1.13 \\
\hline 3 & $\begin{array}{l}\text { Creativity and imagination are essential } \\
\text { elements in the formation of scientific } \\
\text { knowledge }\end{array}$ & $\begin{array}{l}3 \\
(2)\end{array}$ & $\begin{array}{l}6 \\
(3.9)\end{array}$ & $\begin{array}{l}28 \\
(18.4)\end{array}$ & $\begin{array}{l}68 \\
(44.7)\end{array}$ & $\begin{array}{l}47 \\
(30.9)\end{array}$ & 3.99 & .913 \\
\hline 4 & $\begin{array}{l}\text { Creative outcomes are not necessarily } \\
\text { original and new products** }\end{array}$ & $\begin{array}{l}16 \\
(10.5)\end{array}$ & $49(32.2)$ & $\begin{array}{l}42 \\
(27.6)\end{array}$ & $\begin{array}{l}34 \\
(22.4)\end{array}$ & $\begin{array}{l}11 \\
(7.2)\end{array}$ & 2.84 & 1.11 \\
\hline 5 & $\begin{array}{l}\text { Creativity occurs only in the fields of } \\
\text { visual arts, music, drama and artistic } \\
\text { performance** }\end{array}$ & $\begin{array}{l}1 \\
(.7)\end{array}$ & $\begin{array}{l}13 \\
(8.6)\end{array}$ & $\begin{array}{l}10 \\
(6.6)\end{array}$ & $\begin{array}{l}59 \\
(38.8)\end{array}$ & $\begin{array}{l}69 \\
(45.4)\end{array}$ & 4.19 & .94 \\
\hline 6 & $\begin{array}{l}\text { Science contributions facilitate the } \\
\text { development of creativity }\end{array}$ & $\begin{array}{l}3 \\
(2)\end{array}$ & $\begin{array}{l}7 \\
(4.6)\end{array}$ & $\begin{array}{l}39 \\
(25.7)\end{array}$ & $\begin{array}{l}74 \\
(48.7)\end{array}$ & $\begin{array}{l}29 \\
(19.1)\end{array}$ & 3.78 & .876 \\
\hline 7 & $\begin{array}{l}\text { Science teachers must have knowledge } \\
\text { about creativity }\end{array}$ & $\begin{array}{l}0 \\
(0)\end{array}$ & $\begin{array}{l}3 \\
(2)\end{array}$ & $\begin{array}{l}24 \\
(15.8)\end{array}$ & $\begin{array}{l}64 \\
(42.1)\end{array}$ & $\begin{array}{l}61 \\
(40.1)\end{array}$ & 4.2 & .78 \\
\hline 8 & $\begin{array}{l}\text { Creativity is essential for the } \\
\text { development of the educational level of } \\
\text { students in science }\end{array}$ & 2 & $\begin{array}{l}8 \\
(5.3)\end{array}$ & $\begin{array}{l}33 \\
(21.7)\end{array}$ & $\begin{array}{l}73 \\
(48)\end{array}$ & $\begin{array}{l}36 \\
(23.7)\end{array}$ & 3.88 & .88 \\
\hline 9 & $\begin{array}{l}\text { Fostering creativity is essential for } \\
\text { improving the educational performance } \\
\text { of students in science }\end{array}$ & $\begin{array}{l}0 \\
(0)\end{array}$ & $\begin{array}{l}4 \\
(2.6)\end{array}$ & $\begin{array}{l}13 \\
(8.6)\end{array}$ & $\begin{array}{l}67 \\
(44.1)\end{array}$ & $\begin{array}{l}68 \\
(44.7)\end{array}$ & 4.3 & .74 \\
\hline \multicolumn{3}{|c|}{ Total views of creativity in science education } & & & & & 3.76 & .39 \\
\hline
\end{tabular}

Note. ** recoded data of negative items.

Most of the means reached the agreement level and ranged between 3.78 and 4.3; the exceptions were items 8 and 12 , which scored slightly low means $(M=2.74, S D=1.13$ and $M=2.84, S D=1.11$, respectively). The statistical results in Table 3 indicate that participants' creativity is an important element for learning science, and science teachers should understand how to foster students' creativity in the science classroom. In addition, they rejected the idea of relating creativity with only arts and instead believed that creativity should be embedded in the science curriculum to improve students' performance in science education.

Participants also answered a multiple-choice question about how they see science as a school subject. The finding showed that the majority of trainee teachers believed that science is a creative subject; $68.4 \%$ of them saw science as a subject that can foster students' creativity. In contrast, only four participants $(2.6 \%)$ did not view science as a subject that can encourage creativity. About a quarter of the participants believed that science as a subject is sometimes creative $(\mathrm{N}=39,25.7 \%)$.

Although most participants viewed science education as a creative domain, the qualitative findings showed their views of scientific creativity were modest and immature. For example, some interviewees stressed the importance of creativity on the construction of scientific knowledge. They believed that creativity is embedded in the process of conducting scientific inquiries. It appeared from participants' responses that scientists' creativity is the starting point to think about posing research questions and testing hypotheses; "it also answers the research questions" (Majed). Khalid declared that scientists' creative endeavors synchronize the whole procedure of conducting scientific research, and these endeavors "consume a lot of the effort and time of scientists to prove their arguments." However, most interviewees struggled to provide detailed responses regarding the creative process in conducting science, even when they were asked to name some examples of the role scientists' creativity plays. They could not elaborate on their views about creativity in science. 
Yet other interviewees clearly stated that creativity and imagination are not embedded in the NoS. They strongly believed that "scientific research should be destitute of scientist's imagination and creativity" (Marrim). Teachers' reticence about the role of imagination and creativity became more evident when they spoke about the relationship between creativity and the NoS dimensions.

\subsection{Correlations among NoS Dimensions and Creativity}

According Table 6 indicates, trainee teachers' views about creativity are significantly correlated with six dimensions of the NoS: five positive correlations and one reverse correlation.

Table 6. Correlation among Views of Creativity and Dimensions of NoS

\begin{tabular}{llllllll}
\hline Correlation & & $\begin{array}{l}\text { Universal } \\
\text { method }\end{array}$ & $\begin{array}{l}\text { Theory is } \\
\text { invented }\end{array}$ & $\begin{array}{l}\text { Law is } \\
\text { more } \\
\text { certain }\end{array}$ & $\begin{array}{l}\text { Law and } \\
\text { theory are } \\
\text { different }\end{array}$ & $\begin{array}{l}\text { Experimental } \\
\text { facts }\end{array}$ & $\begin{array}{l}\text { Positivist } \\
\text { methodology }\end{array}$ \\
\hline Views of & Correlation & $.269^{* *}$ & $-.265^{* *}$ & $.185^{*}$ & $.264^{* *}$ & $.287^{* *}$ & $.220^{* *}$ \\
Creativity & Sig & .001 & .001 & .022 & .001 & .000 & .006 \\
& $N$ & 152 & 152 & 152 & 152 & 152 & 152 \\
\hline
\end{tabular}

However, all the significant correlations with trainee teachers' views of creativity are less than 0.3 , meaning that the correlations are weak and small. For example, the highest degree was found in the position of science being based on experimental facts $(r=.287, p<.000$, followed by (in descending order) universal method, law and theory being different types of ideas, positivist methodology, and law being more certain than theory $(r=.269, r=.264, r=.220$, and $r=.185$ respectively). The last position was negatively correlated with views of creativity - that is, theory is invented $(r$ $=-.265, p=.001)$.

Although the previous correlations were simple, they indicate that the participants have been affected by the empirical side of science. For example, when we review the most common statements drawn from interviews, it is evident that most trainee teachers believed that scientific knowledge should be value free and isolated from cultural and personal effects; such values and empathy would lead to "unreliable and invalid scientific findings" (Majed). Another female interviewee said that "scientific laws are inevitable and correct 100\%, such as Newton's laws of motion" (Elham). The interviewees believed that "scientific laws stand on facts and evidences" (Khalid) and follow "logical and standardized procedures" (Elham).

On the other hand, participants' concept of creativity in science is related with the existence of the universal scientific method, science based on experimental facts, and science being certain knowledge standing on positivist methodology. It may be more apparent that the participants are affected by the previous dimensions when we review their definition of the concept of scientific creativity. They defined scientific creativity as an output that is characterized as original, empirical, imaginative, and useful. The most frequent attribute of the four attributes mentioned by participants is empiricism, followed by originality. Meanwhile, imagination and usefulness were among the least mentioned attributes in their definition of scientific creativity.

\section{Discussion}

This section discusses the major results of the study in order to draw overall conclusions. Three main issues are derived from the current findings; even so, the three issues are likely to overlap with each other. Thus, this section discusses trainee teachers' views of the NoS dimensions, teachers' overall worldview, and their views about scientific creativity.

The quantitative and qualitative findings addressed how trainee teachers view the dimensions of the NoS. For instance, participants did not hold informed views about the nature of scientific observation; they were perplexed by the extent to which the preconceptions of scientists influenced their research. Therefore, they were frustrated about the nature of observation in terms of whether it is theory laden or theory independent. This result are in line with several studies such as Aslan and Tasar (2013), Aydemir et al. (2017), and Mihladiz and Dogan (2014).

Second, participants appeared to hold unclear views and naïve understanding of the tentativeness of science. They could not identify how scientific knowledge is tentative: Is it tentative via revolutionary, cumulative, or evolutionary process? It was obvious during the interviews that the interviewees limited the tentativeness to theories, and they described scientific laws as more solid knowledge. This indicates that trainee science teachers hold outdated views and perspectives of scientific knowedgle (Aydemir et al. ,2017; and Karişan \& Cebesoy, 2018).

Third, they naïvely claimed that scientific laws are more certain, as some of them literally said that if theories stand for a long time then they should be considered as scientific laws and vice versa. If a law has been disproved, it should be 
considered as theory. They also showed poor understanding of scientific methods because they were more in agreement with the idea that scientific knowledge is gained by universal methods. Even when participants shyly acknowledged the influences of sociocultural, personal, and religious factors, they perceptibly supported the influence of empirical evidence and experimental facts. Overall, this study concluded that trainee science teachers hold naïve views about the NoS. In general, the findings are similar to those of other studies, such as those by Aslan and Tasar (2013), Aydemir et al. (2017), Mihladiz and Dogan (2014), Sairattanain (2018), and Turgut et al. (2016).

However, the findings of the current study contradict the findings of Karişan and Cebesory (2018), who concluded that teachers have advanced thoughts and informed views of the NoS. However, the difference in findings between the two studies is superficial; as Karişan and Cebesory (2018) concluded, teachers appeared knowledgeable when they revealed their own views about specific dimensions of the NoS-namely, inferential dimensions of the NoS. At the same time, the teachers in Karişan and Cebesory's study appeared naïve when they revealed their own thoughts about other aspects of NoS - namely, the subjective dimensions of NoS. Therefore, the detailed results in Karişan and Cebesory's (2018) study are similar to the current study's findings.

In a clearer sense, trainee teachers were informed about certain aspects of the NoS, such as empirical evidence, experimental facts, objective methodology, and universal methods; meanwhile, they showed poor understanding in other aspects of the NoS, such as personal factors, authority, parsimony, sociocultural factors, subjective methodology, and imagination. Trainee teachers' views concurred with the positivist philosophy and appeared traditional in many aspects of the science field.

In terms of scientific creativity, the trainee teachers initially acknowledged that the science subject is a creative one, and students' creativity should be nurtured in science education (Alsahou \& Alsammari, 2019). Nevertheless, their views noticeably changed when they spoke about the NoS aspects because they believed science is a field of discoveries rather than inventions. In addition, they believed scientific laws are more certain and static than theories, as well as believing that scientific knowledge is based on empirical facts and evidence. In the same vein, they devalued the influence of sociocultural and personal factors. Therefore, teachers' misunderstanding of the NoS aspects could generate a poor understanding of the creativeness of both scientists and science education. This may reflect the findings of previous studies on science teachers' views of scientific creativity, which summarized that teachers have modest and ignorant views of scientific innovation, despite their belief that the science curriculum is one of the creative curriculums (e.g., Alsahou, 2015; Alsahou \& Alsammari, 2019; Hong \& Kang, 2010; Liu \& Lin, 2014; Newton \& Newton, 2010). This poor understanding of the NoS aspects can be attributed to the absence of a NoS course at teacher training colleges, where students are not explicitly and implicitly taught about the NoS.

\section{Conclusion}

In summary, trainee science teachers hold naïve beliefs about the NoS and poor understanding of how scientific knowledge is gained. They demonstrated a misunderstanding of many dimensions of the NoS. Their worldview of science also appeared traditional as they viewed scientific findings from a positivist point of view; they also tended to embrace epistemology based on absolutism and objectivism. They naïvely believed that there are universal, unified, and agreed-upon methods for discovering scientific knowledge. Yet despite participants' belief that creativity is an aspect embedded in the NoS, they viewed science to be more related to discoveries than invention. In other words, scientific knowledge already exists, but it needs the finder to discover the truth. The concept of scientific creativity was limited to some scientific practices, such as manipulating lab and hands-on activities as well as inventing new products.

\section{Limitations and Future Research}

No scientific research is devoid of limitations, even if researchers take all precautions. For instance, the study sample was limited to trainee science teachers, so we could not explore how science teachers transfer their NoS views into classroom practices. In addition, the study did not explore trainee science teachers' understanding of the HoS and PoS to investigate possible influences and relationships. Nevertheless, future research can take these limitations into consideration to cover these gaps. Finally, it is recommended that science educators who are responsible for developing science education courses integrate a NoS module to explicitly and implicitly address the influence of the societal, cultural, historical, philosophical, and personal contexts into constructing and performing science. Thus, the current study proposes the following research questions for future studies:

- How do science teachers put their NoS beliefs into the classroom activities?

- How do science teachers foster creativity in science classroom activities?

- To what extend do HoS and PoS courses influence science teachers' views of NoS and scientific creativity? 


\section{Acknowledgements}

This work was supported by the Public Authority of Applied Education and Training PAAET (BE-17-09).

\section{References}

Abd-El-Khalick, F. (2001). Embedding nature of science instruction in preservice elementary science courses: Abandoning scientism, but... Journal of Science Teacher Education, 12(3), $215-233$. https://doi.org/10.1023/a:1016720417219

Abd-El-Khalick, F., Bell, R. L., \& Lederman, N. G. (1998). The nature of science and instructional practice: Making the unnatural natural. Science $\quad$ Education, $417-436$. https://doi.org/10.1002/(SICI)1098-237X(199807)82:4<417::AID-SCE1>3.0.CO;2-E

Akcanca, N., \& Cerrah Ozsevgec, L. (2018). Effect of activities prepared by different teaching techniques on scientific creativity levels of prospective pre-school teachers. European Journal of Educational Research, 7(1), 71-86. https://doi.org/10.12973/eu-jer.7.1.71

Aljughaiman, A., \& Mowrer-Reynolds, E. (2005). Teachers' conceptions of creativity and creative students. Journal of Creative Behavior, 39(1), 17-34. https://doi.org/10.1002/j.2162-6057.2005.tb01247.x

Alsahou, H. (2015). Teachers" beliefs about creativity and practices for fostering creativity in science classroom in the State of Kuwait. (PhD thesis, University of Exeter).

Alsahou, H., \& Alsammari, A. (2019). Beliefs About Scientific Creativity Held by Pre-Service Science Teachers in the State of Kuwait. International Education Studies, 12(10), 37-49. https://doi.org/10.5539/ies.v12n10p37

Aslan, O., \& Taşar, M. F. (2013). How do science teachers view and teach the nature of science? A classroom investigation. Ĕgitim ve Bilim, 38(167), 65-80.

Aydemir, S., Ugras, M., Cambay, O., \& Kilic, A. (2017). Trainee pre-school teachers' views on the nature of science and scientific inquiry. Üniversitepark Bülten/Universitepark Bulletin, 2(6), 74-87.

Burns, R. B. (1997). Introduction to Research Methods. 3rd Edition, Addison Wesley Longman Australia, South Melbourne.

Chen, S. (2006a). Development of an instrument to assess views on nature of science and attitudes toward teaching science. Science Education, 90(5), 803-819. https://doi.org/10.1002/sce.20147

Chen, S. (2006b). Views on science and education (VOSE) questionnaire. Asia-Pacific Forum on Science Learning and Teaching, 7(2), article 11

Clough, M. P., \& Olson, J. K. (2007). Teaching and assessing the nature of science: An introduction. Science \& Education, 17(2-3), 143-145. https://doi.org/10.1007/s11191-007-9083-9

Creswell, J. W. (2002). Educational research: Planning, conducting, and evaluating quantitative and qualitative approaches to research. Upper Saddle River, NJ: Merrill/Pearson Education

Diakidoy, I. N., \& Kanari, E. (1999). Student teachers' beliefs about creativity. British Educational Research Journal, 25(2), 225-243. https://doi.org/10.1080/0141192990250206

Fryer, M. (1996). Creative teaching and learning. London: Paul Chapman Publishing, Ltd.

Good, R., Lederman, N., Gess-Newsome, J., McComas, W., \& Cummins, C. (2000). Nature of science: Implications for research, assessment, and teacher education. A symposium and paper presented at the annual international meeting of the Association for the Education of Teachers in Science, Akron, $\mathrm{OH}$

Hanuscin, D. L., Lee, M. H., \& Akerson, V. L. (2010). Elementary teachers' pedagogical content knowledge for teaching the nature of science. Science and Education, 95(1), 145-167. https://doi.org/10.1002/sce.20404

Hodson, D. (2009). Teaching and learning about science: language, theories, methods, history, traditions and values. Rotterdam: Sense Publishers. https://doi.org/10.1163/9789460910531

Hong, M., \& Kang, N. H. (2009). South Korean and the US secondary school science teachers' conceptions of creativity and teaching for creativity. International Journal of Science and Mathematics Education, 8(5), 821-843. https://doi.org/10.1007/s10763-009-9188-5

Jeffrey, B. (2006). Creative teaching and learning: towards a common discourse and practice. Cambridge Journal of Education, 36(3), 399-414. https://doi.org/10.1080/03057640600866015

Jeffrey, B., \& Craft, A. (2004). Teaching creatively and teaching for creativity; distinctions and relationships. Educational Studies, 30(1), 77-87. https://doi.org/10.1080/0305569032000159750 
Johnston, J. (2009). What is creativity in science education. In A. Wilson (Ed.), Creativity in primary education ( $2^{\text {nd }}$ ed.; pp. 88-101). Exeter: Learning Matters.

Kampylis, P. (2010). Fostering creative thinking - The role of primary teachers (Jyväskylä Studies in Computing No. 115, S. Puuronen, Ed.). Jyväskylä, Finland: University of Jyväskylä. Retrieved June 10, 2011, from http://urn.fi/URN:ISBN:978-951-39-3940-3

Karışan, D., \& Cebesoy, Ü. B. (2018). Exploration of preservice science teachers' nature of science understandings. Pamukkale Üniversitesi Eğitim Fakültesi Dergisi, 44(44), 161-177. https://doi.org/10.9779/PUJE.2018.212

Kimball, M. E. (1967). Understanding the nature of science: A comparison of scientists and science teachers. Journal of Research in Science Teaching, 5, 110-120. https://doi.org/10.1002/tea.3660050204

Kourany, J. A. (1998). Scientific knowledge: Basic issues in the philosophy of science. Belmont, CA: Wadsworth Publishing Company. Leden, L., \& Hansson, L. (2017). Nature of science progression in school year 1-9: A case study of teachers' suggestions and rationales. Research in Science Education, 49(2), 591-611. https://doi.org/10.1007/s11165-017-9628-0

Lee, E. A., \& Kim, K. H. (2005). Korean science teachers' understanding of creativity in gifted education. The Journal of Secondary Gifted Education, 2(3), 98-105. https://doi.org/10.4219/jsge-2005-476

Lin, Y. S. (2011). Fostering Creativity through Education-A Conceptual Framework of Creative Pedagogy. Creative Education, 2(3), 149-155. https://doi.org/10.4236/ce.2011.23021

Liu, S., \& Lin, H. (2014). Primary teachers' beliefs about scientific creativity in the classroom context. International Journal of Science Education, 36(10), 1551-1567, https://doi.org/10.1080/09500693.2013.868619

McComas, W. F., Clough, M. P., \& Almazroa, H. (1998). The role and character of the nature of science in science education. In The nature of science in science education: Rationales and strategies (pp. 3-39). Dordrecht: Kluwer Academic. https://doi.org/10.1007/0-306-47215-5_1

Mihladız, G., \& Doğan, A. (2014). Science teachers' views about NOS and the place of NOS in science teaching. Procedia-Social and Behavioral Sciences, 116, 3476-3483. https://doi.org/10.1016/j.sbspro.2014.01.787

Mohammed, B. (2006). Promoting creativity in early childhood education in Brunei (Unpublished PhD thesis). University of Western Australia.

NACCCE. (1999). All our futures: creativity, culture and education. Report of the National Advisory Committee on Creative and Cultural Education. Sudbury: DfEE.

Newton, D. P., \& Newton, L. D. (2009). Some student teachers' conceptions of creativity in school science. Research in Science and Technological Education, 27(1), 45-60. https://doi.org/10.1080/02635140802658842

Newton, D. P., \& Newton, L. D. (2010). Engaging science: Trainee primary school teachers' notions of engaging science lessons. International Journal of Science \& Mathematics Education, 9(2), 327-345. https://doi.org/10.1007/s10763-010-9244-1

Newton, D. P., \& Newton, L. D. (2011). Engaging science: Pre-service primary school teachers' notions of engaging science lessons. International Journal of Science \& Mathematics Education, 9(2), 327-345. https://doi.org/10.1007/s10763-010-9244-1

Osborne, J., \& Dillon, J. (2008). Science education in Europe: Critical reflections. London: The Nuffield Foundation.

Park, H., Nielsen, W., \& Woodruff, E. (2013). Students' conceptions of the nature of science: perspectives from Canadian and Korean middle school students. Science \& Education, 23(5), 1169-1196. https://doi.org/10.1007/s11191-013-9613-6

Park, S., Lee, S., Oliver, J. S., \& Crammond, B. (2006). Changes in Korean science teachers' perception of creativity and science teaching after participating in an overseas professional development program. Journal of Science Teacher Education, 17, 37-64. https://doi.org/10.1007/s10972-006-9009-4

Ripple, R. E. (1999). Teaching creativity. In M. A. Runco \& S. R. Prirzer (Eds.), Encyclopedia of creativity (pp. 629-638). San Diego, CA: Academic Press.

Rubba, P. A., \& Andersen, H. (1978). Development of an instrument to assess secondary school students' understanding of the nature of scientific knowledge. Science Education, 62(4), 449-458. https://doi.org/10.1002/sce.3730620404

Sairattanain, S. (2018). Trainee science teachers' understanding of the nature of science: An examination and implications for further development. Human Behavior, Development and Society, 19, 84-91. 
Schwartz, R. S., \& Lederman, N. G. (2002). "It's the nature of the beast": The influence of knowledge and intentions on learning and teaching nature of science. Journal of Research in Science Teaching, 39, 205-236. https://doi.org/10.1002/tea.10021

Showalter, V. (1974). What is unified science education? Program objectives and scientific literacy (Part 5). Prism II, 2(3-4).

Turgut, H., Es, H., Altan, E., \& Ozturk, N. (2016). Trainee pre-school teachers' perceptions of science and pseudo-science. International Journal of Educational Sciences, 8(1), 150-169. https://doi.org/10.15345/iojes.2016.01.013

Tyupa, S. (2011). A theoretical framework for back-translation as a quality assessment tool. New Voices in Translation Studies, 7, 35-46.

Wellington, J. (2000). Educational research: Contemporary issues and practical approaches. London: Continuum.

\section{Copyrights}

Copyright for this article is retained by the author(s), with first publication rights granted to the journal.

This is an open-access article distributed under the terms and conditions of the Creative Commons Attribution license which permits unrestricted use, distribution, and reproduction in any medium, provided the original work is properly cited. 